This article was downloaded by: [Memorial University of Newfoundland] On: 21 January 2015, At: 08: 17

Publisher: Routledge

Informa Ltd Registered in England and Wales Registered Number: 1072954

Registered office: Mortimer House, 37-41 Mortimer Street, London W1T

3J H, UK

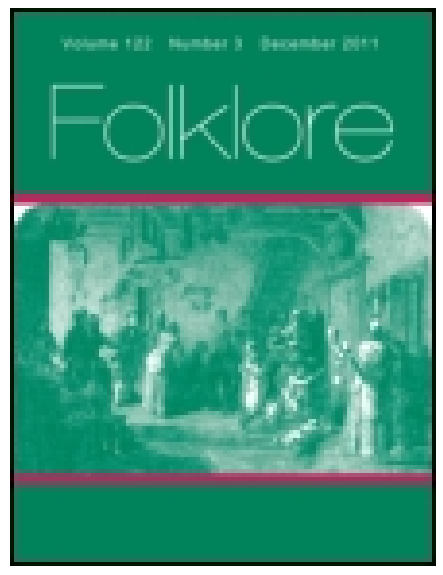

\title{
Folklore
}

Publication details, including instructions for authors and subscription information:

http:// www. tandfonline.com/loi/ rfol20

\section{Folklore from Essex}

\author{
J. B. Partridge
}

Published online: 01 Feb 2012.

To cite this article: J. B. Partridge (1914) Folklore from Essex, Folklore, 25:3, 373-374, DOI: 10.1080/0015587X.1914.9718843

To link to this article: http:// dx. doi. org/ 10.1080/0015587X.1914.9718843

\section{PLEASE SCROLL DOWN FOR ARTICLE}

Taylor \& Francis makes every effort to ensure the accuracy of all the information (the "Content") contained in the publications on our platform. However, Taylor \& Francis, our agents, and our licensors make no representations or warranties whatsoever as to the accuracy, completeness, or suitability for any purpose of the Content. Any opinions and views expressed in this publication are the opinions and views of the authors, and are not the views of or endorsed by Taylor \& Francis. The accuracy of the Content should not be relied upon and should be independently verified with primary sources of information. Taylor and Francis shall not be liable for any losses, actions, claims, proceedings, demands, costs, expenses, damages, and other liabilities whatsoever or howsoever caused arising directly or indirectly in connection with, in relation to or arising out of the use of the Content.

This article may be used for research, teaching, and private study purposes. Any substantial or systematic reproduction, redistribution, reselling, loan, sub-licensing, systematic supply, or distribution in any form to anyone is 
expressly forbidden. Terms $\&$ Conditions of access and use can be found at http://www.tandfonline.com/page/terms-and-conditions 
edge of a woman's skirt has become turned up so as to form a kind of pocket, some good fortune, such as a present of a new dress, will come to the owner.

T. E. LONES.

\section{BUbbling WELls in SOMERSET.}

On the first three Sundays in May people visited, and perhaps do still, three wells at Taunton. When the water bubbled patients stood in the wells and were cured of "any humours." On these days after twelve o'clock young men used to play "birn ball " in the streets.

J. B. Partridie.

Epiphany and Easter Observances in Westmoreland.

On the Eve of the Epiphany, at Brough-under-Stainmore, there is an annual procession called "The Carrying of the Holling" or Holy tree (see Parliamentary Gazette, 1843, vol. i., p. 297). In this and the neighbouring counties young folk or mumners used to perform a sort of play, and begged for pace eggs. At Kendal children still gather in the Castle Fields for "Jerring of Pace Eggs" on Easter Tuesday. The eggs which were unbroken were hailed as "conquerors." The game of "Grandy Needles" consisted of a line of young men on one side and young women on the other, forming an arch, under which they all passed in succession. This game, which took place on Easter Tuesday, ceased about 1860. (Mr. G. Rushforth, parish clerk, Kendal, in I906.)

J. B. Partridge.

FOLKLORE FROM ESSEX.

Watching the Wardstaffe-At Ongar and Harlow, lands were held by the service of watching the Wardstaffe, which was cut 
yearly on Low Sunday, by the Bailiff of the Hundred, from some willow bough growing in Abbotte-Rothing Wood. ${ }^{1}$

Inhabitants of the Manor of Loughton had the right of lopping trees for firewood in Epping Forest from St. Martin's Day to St. George's Day. It was said to be due to a grant from Queen Elizabeth, and to be "conditional on their commencing to lop the trees as the clock struck midnight on the preceding night. They were wont to meet for that purpose at Staples Hill, within the Forest, where, after lighting a fre, and celebrating the occasion with draughts of beer, they lopped from twelve o'clock till two o'clock, and then returned to their homes. The branches, according to the custom, could not be faggoted in the Forest, but were made into heaps, six feet high, and were then drawn out of the Forest on sledges. In olden times the first load was drawn out by white horses."

The wood could only be cut for the use of the inhabitants of the Parish. It was done for the last time in $1879 .{ }^{2}$

J. B. Partridge.

\section{GloucestershiRe LEGends.}

Legend of the Cleeve Hill Stone.-Between Marl Cleeve and Offenham, on the left bank of the Avon, is a long, and almost straight ridge, which slopes down abruptly to the river and its meadows. Along its brow runs an old (reputedly Roman) road; and where this is crossed by a way leading from the village of Prior's Cleeve to Cleeve Mill, is a prehistoric barrow, upon which is a heavy mass of stone, evidently the base of a fourteenth century wayside cross. The presence of this stone is accounted for by a legend.

Once upon a time, the Devil perched on Meon Hill (in Quinton, Co. Gloucester), and looking towards Evesham, was annoyed by the sight of its Abbey, then in great prosperity. There being a big stone at hand, he kicked it at the Abbey with malicious

1 See Morant's History of Essex, i. 126.

Eversley, Commons, Forests, and Footpaths, 1910, p. 67. 